\title{
KERAGAAN BIOREPRODUKSI DAN PERTUMBUHAN TIGA POPULASI IKAN BAUNG (Hemibagrus nemurus Val. 1840)
}

\author{
Jojo Subagja\#, Wahyulia Cahyanti, Nunak Nafiqoh, dan Otong Zenal Arifin \\ Balai Penelitian dan Pengembangan Budidaya Air Tawar \\ (Naskah diterima: 2 April 2014; Revisi final: 27 Februari 2015; Disetujui publikasi: 11 Maret 2015)
}

\begin{abstract}
ABSTRAK
Ikan baung (Hemibagrus nemurus Val. 1840) termasuk kelompok catfish bernilai ekonomis, di Asia populer dengan nama "green catfish". Informasi tentang variasi genetik dan keragaan bioreproduksi dari ketiga kandidat populasi hasil kegiatan 2011, yaitu: populasi Cisadane (Sdn), Cirata (Crt), dan Serayu (Sry) telah dijadikan informasi dasar dalam keperluan seleksi atau persilangan antar strain agar diperoleh ikan yang cepat tumbuh. Populasi Serayu menunjukkan tingkat variasi genetik paling kecil, namun memiliki aspek bioreproduksi lebih baik, sementara populasi Cirata menunjukkan kekerabatan dan variasi genetik lebih tinggi dari populasi Serayu dan Cisadane. Penelitian ini bertujuan untuk mengetahui keragaan bioreproduksi dan pertumbuhan hasil persilangan dari tiga populasi yang digunakan. Keturunan hasil persilangan antara ketiga populasi telah diamati pada aspek Spesific Growth Rate (SGR), bobot akhir, dan sintasan (SR) pada stadia benih umur 42 hari, serta parameter bioreproduksi dari masing-masing populasi induk antara lain: perkembangan gonad, fekunditas, dan indeks ova somatik. Hasil persilangan antara populasi Sdn x Sry menghasilkan nilai heterosis tertinggi pada parameter SGR $(8,72 \%)$; heterosis sintasan tertinggi dicapai oleh persilangan Sry dengan Sdn (45,45\%); sedangkan bobot akhir dicapai oleh persilangan Crt dengan Sdn (22,08\%). Persilangan dua arah antara populasi Cisadane dan populasi Cirata adalah persilangan dengan respons tertinggi pada parameter SR dan bobot akhir nilai IOS (Indeks Ova Somatik) Cisadane 15,9\% dan Cirata $20,7 \%$.
\end{abstract}

KATA KUNCI: ikan baung, persilangan, intraspesifik, heterosis

ABSTRACT: Bioreproduction and growth performance from three different population of Hemibargus fish (Hemibagrus nemurus, Val. 1840). By:Jojo Subagja, Wahyulia Cahyanti, Nunak Nafiqoh, and Otong Zenal Arifin

Green catfish (Hemibagrus nemurus Val. 1840) was known as high economical catfish in Southeast Asia. Genetic divergence and bioreproduction analysis were done on 2011, these analysis consist of three populations; Cisadane (Sdn), Cirata (Crt), and Serayu (Sry). The analysis shows that Serayu population has less genetic variation but best bioreproduction performance compare to the other population, in the other hand Cirata population has highest genetic variation among analyzed population. The aim of the study is to explore the superior characteristic of each strain using intraspesific cross-breeding. Monitoring of the offsprings consist of; Specific Growth Rate (SGR), final weight, and survival rate (SR) on 42 days larvae. Meanwhile gonad development, fecundity, and ova-somatic index were monitored from the broodfish. The result shows cross-breeding of Sdn x Sry represent the highest value of SGR heterosis (8.72\%), SR heterosis value was highest on Sry $x$ Sdn cross-breeding (45.45\%) and Crt x Sdn offsprings have highest value on final weight (22.08\%). Two way cross-breeding between Cisadane and Cirata population was the best response based on survival rate (SR) and final growth parameters. Cisadane and Cirata population also have high productivity described by OSI (Ova Somatic Index) value, 15.9\% for Cisadane population and 20.7\% for Cirata population.

KEYWORDS: $\quad$ green catfish, cross-breeding, intraspesific, heterosis

\# Korespondensi: Balai Penelitian dan Pengembangan Budidaya Air Tawar. Jl. Raya Sempur No. 1, Bogor 16154 , Indonesia. Tel.: + (0251) 8313200

E-mail: subagja.j@gmail.com 


\section{PENDAHULUAN}

Ikan baung (Hemibagrus nemurus Val. 1840) merupakan salah satu komoditas ikan air tawar ekonomis penting di Indonesia dan telah populer di kalangan konsumen dalam negeri, serta di wilayah Asia Tenggara. Ikan ini memiliki kualitas daging yang baik, sehingga harga cukup tinggi dibandingkan dengan jenis ikan air tawar lainnya (Boyoun et al., 2010). Namun demikian, komersialisasi dan budidaya intensif terhadap spesies ini masih terbatas, karena ketidakmampuan untuk berkembang biak secara alamiah di tempat penangkaran, penyediaan benih untuk pembesaran sebagian besar masih mengandalkan tangkapan dari alam. Demikian juga informasi genetik tentang $H$. nemurus agak terbatas. Oleh karena itu, mencari cara untuk meningkatkan efisiensi produksi melalui studi genetika harus menjadi tujuan langsung pada budidaya ikan baung.

Informasi keragaan genetik, karakterisasi morfometrik, dan bioreproduksi dari masing-masing koleksi perlu diketahui lebih awal. Hal ini akan memudahkan dalam penentuan langkah selanjutnya dalam pemuliaan, apakah cukup dengan dilakukan hibridisasi atau perlu dilakukan seleksi, dengan demikian akan mempercepat dalam mencapai tujuan budidaya yaitu peningkatan produksi dan efisiensi (Nugroho et al., 2003). Program pemuliaan merupakan kegiatan untuk meningkatkan atau mengubah sifat kuantitatif dengan cara yang telah ditentukan, salah satu cara adalah melalui hibridisasi (Kurniasih \& Gustiano, 2007).

Hibridisasi adalah proses perkawinan antar individu dari spesies yang berbeda (persilangan interspesifik) atau individu genetik berbeda dari spesies yang sama (persilangan intraspesifik). Hibridisasi adalah program persilangan yang dapat diaplikasikan pada ikan, udang, kerang-kerangan maupun rumput laut. Hasil dari program ini dapat menghasilkan individu-individu yang unggul, kadang juga steril dan dapat pula menghasilkan strain baru. Teknik persilangan merupakan suatu teknik pemuliaan yang bertujuan untuk memperbaiki laju pertumbuhan, menunda kematangan gonad, dan meningkatkan ketahanan terhadap penyakit, serta untuk menciptakan benih unggul. Persilangan dapat dilakukan secara acak maupun terarah, di mana keturunan yang diperoleh sesuai dengan tetuanya. Persilangan yang bersifat acak dan terorientasi memungkinkan penyebaran karakter yang baik (Lawrence, 2000).

Tipe persilangan interspesifik dan intraspesifik dilaporkan mampu meningkatkan keragaan benih pada ikan Cichlidae (Oreochromis mossambicus x Oreochromis niloticus), ikan Pangasiid (Pangasius hypophthalmus $\mathrm{x}$ Pangasius djambal), ikan Clariid (Clarias meladerma $\mathrm{x}$ Clarias gariepinus), ikan mas Cyprinus carpio (strain
Majalaya x strain Sinyonya) (Kurniasih \& Gustiano, 2007), udang galah Macrobrachium rosenbergii (strain GIMacro x strain Barito) (Wuwungan, 2009). Eksploitasi sifat unggul melalui hibridisasi dapat diperoleh melalui mekanisme heterosis yaitu aksi gen dominansi pada individu heterozigot (hybrid vigour) (Tave, 1995).

Penyediaan benih pada kondisi sekarang masih mengalami kendala terutama pada fase benih pada ikan baung sampai dengan ukuran $5 \mathrm{~cm}$, sintasan benih masih rendah dan berfluktuasi antara 10\%-30\%. Tingginya angka kematian ikan baung ukuran benih $(<5 \mathrm{~cm})$ kebanyakan kasus disebabkan oleh kanibalisme dan serangan parasit "ich" (white-spot) dan waktu terjadinya serangan hampir saat ikan mencapai ukuran panjang badan 2-2,5 cm (Komunikasi pribadi). Terjadinya kematian benih baung tersebut disebabkan oleh beberapa hal antara lain: 1) faktor dalam, yaitu keterkaitan dengan genetik yang diekspresikan dengan kelenturan fenotipe dalam adaptasi terhadap lingkungan. Bisa dimaklumi panti-panti benih ikan baung selama ini untuk menghasilkan benih, berasal dari induk alam, sudah pasti sifat-sifat yang liar masih dimiliki, menyebabkan ikan mudah stres; 2) faktor luar, yaitu peranan lingkungan pemeliharaan seperti: kadar oksigen terlarut, fluktuasi suhu air pemeliharaan dan kurang higienis media pemeliharaan (Taukhid et al., 2005).

Dengan hibridisasi diharapkan terdapat peningkatan mutu genetik dari "hybride vigoure" $(\mathrm{H})$ yang langsung dapat dirasakan dalam budidaya pembesaran oleh petani. Tujuan kegiatan penelitian ini adalah memperoleh benih unggul melalui persilangan antar populasi ikan baung yang ada, sekaligus untuk menghasilkan calon induk F-1 dari masing-masing populasi ikan baung penghasil hibrida diawali dengan kegiatan identifikasi dan karakterisasi (Subagja et al., 2011), bioreproduksi induk dan lebih difokuskan pada eksplorasi performa hibridisasi dari tiga populasi terpilih.

\section{BAHAN DAN METODE}

Penelitian dilakukan dengan rincian kegiatan sebagai berikut:

\section{Tempat Pelaksanaan Kegiatan Penelitian}

Penelitian pemeliharaan induk dilakukan di kolam tembok di Instalasi Penelitian dan Pengembangan Toksikologi dan Lingkungan Cibalagung, dan pemeliharaan benih sampai ukuran 2-3 cm dilakukan di laboratorium basah BPPBAT Sempur, serta pendederan sampai mencapai ukuran 5-8 cm dilakukan di kolam Instalasi Penelitian dan Pengembangan Plasma Nutfah Cijeruk. 


\section{Pola Persilangan}

Induk yang digunakan dalam penelitian ini adalah induk ikan baung yang berasal dari tiga populasi yang berbeda, yaitu: Cisadane (Sdn), Serayu (Sry), dan Cirata (Crt). Performa ikan betina dari ketiga populasi tertera pada Gambar 1.

Persilangan ketiga populasi ikan baung tersebut dilakukan secara resiprok dengan skema persilangan terlihat pada Tabel 1 .

\section{Pemilihan Induk dan Pemijahan}

Induk dipelihara di kolam tembok luasan $20 \mathrm{~m}^{2}$ dan diisi ikan sebanyak 20 ekor dengan rasio pemeliharaan 15 ekor betina dan lima ekor jantan. Ikan diberi pakan buatan kadar protein $28 \%-30 \%$, diberikan sebanyak 3\% dari biomassa yang didistribusikan dua kali sehari, yaitu pagi hari sekitar pukul 8.00 dan sore hari pukul 18.00. Kematangan gonad diamati secara periodik (setiap satu bulan) dengan mengukur sampel diameter oosit dari masing-masing induk betina.

Ikan jantan untuk proses pemijahan dipilih berdasarkan kriteria panjang genital papilla yang sudah melewati pangkal sirip anal (Gambar 2).

\section{Pemeliharaan Benih}

Pemeliharaan larva hasil persilangan dilakukan pada wadah akuarium volume $80 \mathrm{~L}$, berfungsi sebagai wadah penetasan dan pemeliharaan sampai dengan umur 21 hari (mencapai ukuran kisaran 2-2,5 cm) yang dilakukan di dalam ruangan. Pakan awal diberikan kepada larva umur menetas $(\mathrm{H}+45 \mathrm{jam})$ berupa nauplii Artemia diberikan secara ad satiation sampai umur $\mathrm{H}+5$ hari, dan selanjutnya diganti dengan Tubifex diberikan selama tujuh hari, mulai hari ke-12 sampai dengan hari ke-21 diberikan pakan buatan berupa remah dengan kadar protein sekitar 45\%. Hari ke-22 benih didederkan ke kolam (luar ruangan) menggunakan hapa hijau ukuran $2 \mathrm{~m}$ x $1 \mathrm{~m}$ x 0,9 m; padat tebar 700 ekor/hapa. Benih ikan diberi pakan komersial dengan kadar protein berkisar $35 \%-40 \%$ berbentuk remah jumlah ransum harian sebesar $10 \%$.

\section{Parameter Uji dan Analisis Data}

Sampling pertumbuhan anakan dilakukan setiap dua minggu meliputi: pengamatan bobot individu, panjang badan, dan jumlah ikan.

Parameter yang diamati meliputi: laju pertumbuhan spesifik (SGR), bobot akhir, sintasan, nilai heterosis dari masing-masing hibrida, serta beberapa parameter sifat fisika-kimia air.

Koefisien keragaman menunjukkan seberapa besar ukuran panjang badan ikan dalam satu populasi menyebar dari nilai rata-ratanya. Menurut Singh \& Chaudary (1977), koefisien keragaman fenotip (KVF) dirumuskan sebagai berikut:
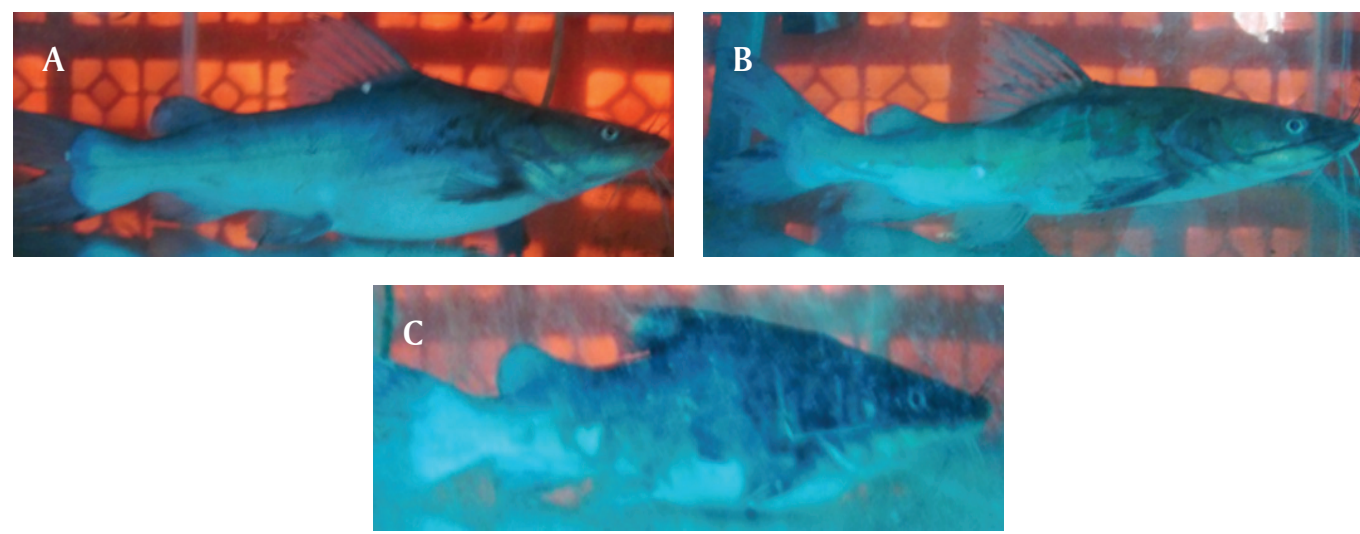

Gambar 1. Induk ikan baung dari Cisadane (A), Serayu (B), dan Cirata (C)

Figure 1. Green catfish broodstock from Cisadane (A), Serayu (B), and Cirata (C)

Tabel 1. Skema persilangan tiga populasi ikan baung secara resiprok

Table 1. Resiprocally cross-breeding scheme of green catfish from three different population

\begin{tabular}{lcccc}
\hline \multirow{2}{*}{$\begin{array}{c}\text { Sumber genetik induk } \\
\text { Genetic resources of broodstock }\end{array}$} & \multicolumn{3}{c}{ Jantan (Male) } \\
\cline { 3 - 5 } & Sdn & Cisadane (Sdn) & Serayu (Sry) & Cirata (Crt) \\
\hline \multirow{3}{*}{ Betina (Female) } & Sry & Sry x Sdn & Sdn x Sry & Sdn x Crt \\
& Crt & Crt x Sdn & Sry x Sry & Sry x Crt \\
& & Crt x Sry & Crt x Crt \\
\hline
\end{tabular}



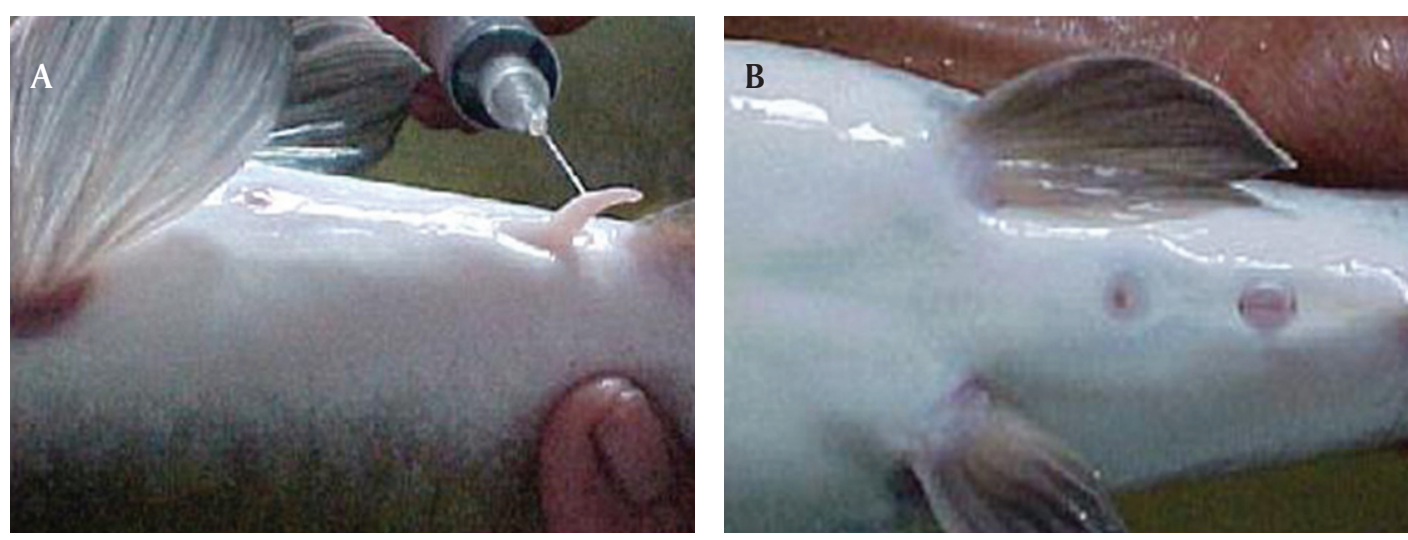

Gambar 2. Kriteria morfologi genitalia induk ikan baung jantan (A) dan betina (B) yang matang gonad

Figure 2. Gonadal maturation by urogenital morphology of male (A) and female (B) green catfish broodstock

$$
\mathrm{KVF}=\frac{\sqrt{\delta f}}{\mathrm{X}} \times 100
$$

di mana:

$\delta f=$ Ragam fenotipe

$\mathrm{X}=$ Rata-rata umum

Laju pertumbuhan harian (Specific Growth Rate / SGR) benih, dalam penelitian ini dihitung menggunakan rumus:

$$
\operatorname{SGR}(\%)=\frac{\ln W t-\ln W o}{t} \times 100 \%
$$

di mana:

$\mathrm{Wt}=$ Bobot rata-rata ikan pada saat akhir $(\mathrm{g})$

Wo $=$ Bobot rata-rata ikan pada saat awal $(\mathrm{g})$

$\mathrm{t}=$ Lama perlakuan (hari)

Sintasan (Survival rate / SR) benih yaitu perbandingan benih yang hidup hingga akhir pemeliharaan terhadap jumlah benih pada awal pemeliharaan dengan menggunakan rumus:

$$
\mathrm{SR}(\%)=(\mathrm{Nt} / \mathrm{No}) \times 100 \%
$$

di mana:

$\mathrm{Nt}=$ Jumlah benih ikan pada akhir pemeliharaan (ekor) No $=$ Jumlah benih ikan pada awal pemeliharaan (ekor)

Nilai Heterosis $(\mathrm{H})$ dapat dihitung dengan menggunakan rumus:

$$
H(\%)=\frac{\{(\mathrm{AB}+\mathrm{BA}) / 2\}-\{(\mathrm{AA}+\mathrm{BB}) / 2\}}{(\mathrm{AA}+\mathrm{BB}) / 2} \times 100 \%
$$

di mana:

$(\mathrm{AB}+\mathrm{BA})=$ Komponen hibrida resiprok

$\mathrm{AA}$ atau $\mathrm{BB}=$ Komponen true breeding

Data sintasan benih dan laju pertumbuhan harian, ditabulasi dan dianalisis menggunakan program Microsoft Excel 2007 dan SPSS 16.0.

\section{HASIL DAN BAHASAN}

Produktivitas induk betina dari masing-masing populasi hasil pemijahan tertera pada Tabel 2. Populasi Cirata menghasilkan indeks ova somatik tertinggi yaitu 20,7\%; serta produksi spermatozoa sebelum dilakukan pengenceran berkisar antara $0,3 \mathrm{~mL}$ sampai $0,4 \mathrm{~mL}$.

Laju pertumbuhan benih meningkat dengan kecepatan yang relatif sama antar populasi dan membentuk pola yang sama pada semua tipe persilangan. Dari sembilan sumber genetik yang dihasilkan, benih hasil persilangan antara Sdn x Sry menghasilkan bobot akhir tertinggi dibandingkan dengan hasil persilangan lainnya. Pada pengamatan ke-3 (umur enam minggu) rataan bobot akhir dicapai adalah $2,2 \pm 0,228$ $\mathrm{g}$; menunjukkan peningkatan sebesar $30,01 \%$ dari tetuanya atau $24,35 \%$ dari semua hasil persilangan, sementara hasil persilangan Sry x Sdn menghasilkan rataan bobot akhir terendah yaitu $0,96 \pm 0$.

Laju pertumbuhan benih meningkat dengan kecepatan yang berbeda antar populasi namun membentuk pola yang sama pada semua tipe persilangan. Pertumbuhan tertinggi ditunjukkan pada persilangan $+\mathrm{Crt} \times \mathrm{Crt} \delta$, sedangkan pertumbuhan terendah pada persilangan o Sry x Sdn ơ (Gambar 3). Berdasarkan analisis statistik, rataan laju pertumbuhan harian menunjukkan perbedaan sangat nyata $(\mathrm{P}<0,01)$. Nilai SGR terbaik terdapat pada persilangan $\operatorname{Crt} x \operatorname{Crt}(6,10 \pm$ $\left.0,16^{\mathrm{a}} \%\right)$, dan SGR terendah adalah pada persilangan Sry x Sdn (3,53 $\pm 0,080^{\text {d } \%) ~(T a b e l ~ 3) . ~}$

Pengaruh induk betina atau induk jantan pada tiga populasi hibrida terhadap perubahan nilai SGR menunjukkan perbedaan nyata $(\mathrm{P}<0,05)$ dari masingmasing konstribusi jenis kelamin, nilai konstribusi induk betina, dan jantan tertinggi dicapai oleh populasi Crt. Melihat kondisi demikian, hibrida dari induk asal Crt lebih cepat beradaptasi terhadap lingkungan pemeliharaan yang diekspresikan dengan pertumbu- 
Tabel 2. Produktivitas ikan baung betina yang terpilih berdasarkan modul diameter optimum, fekunditas telur yang ovulasi, serta produksi spermatozoa hasil pembedahan

Table 2. The selected green catfish broodstock based on optimum module eggs diameter, ovulated eggs fecundity, and spermatozoa production

\begin{tabular}{lcccccc}
\hline $\begin{array}{c}\text { Populasi ikan } \\
\text { (Nomor tagging) } \\
\text { Fish population } \\
\text { (Tagg number) }\end{array}$ & $\begin{array}{c}\text { Bobot betina } \\
\text { Female body } \\
\text { weight }(\mathrm{g})\end{array}$ & $\begin{array}{c}\text { Modul } \emptyset \text { telur } \\
\text { Oocyte diameter } \\
(\mathbf{m m})\end{array}$ & $\begin{array}{c}\text { Fekunditas } \\
\text { (butir/kg) } \\
\text { Fecundity } \\
\text { (eggs.kg-1) }\end{array}$ & $\begin{array}{c}\text { Indeks ova } \\
\text { somatik } \\
\text { Gonad somatic } \\
\text { index (\%) }\end{array}$ & $\begin{array}{c}\text { Bobot jantan } \\
\text { Male body } \\
\text { weight }(\mathrm{g})\end{array}$ & $\begin{array}{c}\text { Produksi } \\
\text { sperma } \\
\text { Sperm pro- } \\
\text { duction (mL) }\end{array}$ \\
\hline $\begin{array}{l}\text { Cisadane (Sdn) } \\
000669 \text { C473 }\end{array}$ & 560 & $1.42 \pm 0.090$ & 55,600 & 15.9 & 500 & 0.4 \\
$\begin{array}{l}\text { Serayu (Sry) } \\
\text { 000 66B 33BB } \\
\text { Cirata (Crt) }\end{array}$ & 540 & $1.42 \pm 0.109$ & 41,600 & 15.4 & 460 & 0.3 \\
000669 C863 & 480 & $1.39 \pm 0.068$ & 61,400 & 20.7 & 450 & 0.3 \\
\hline
\end{tabular}

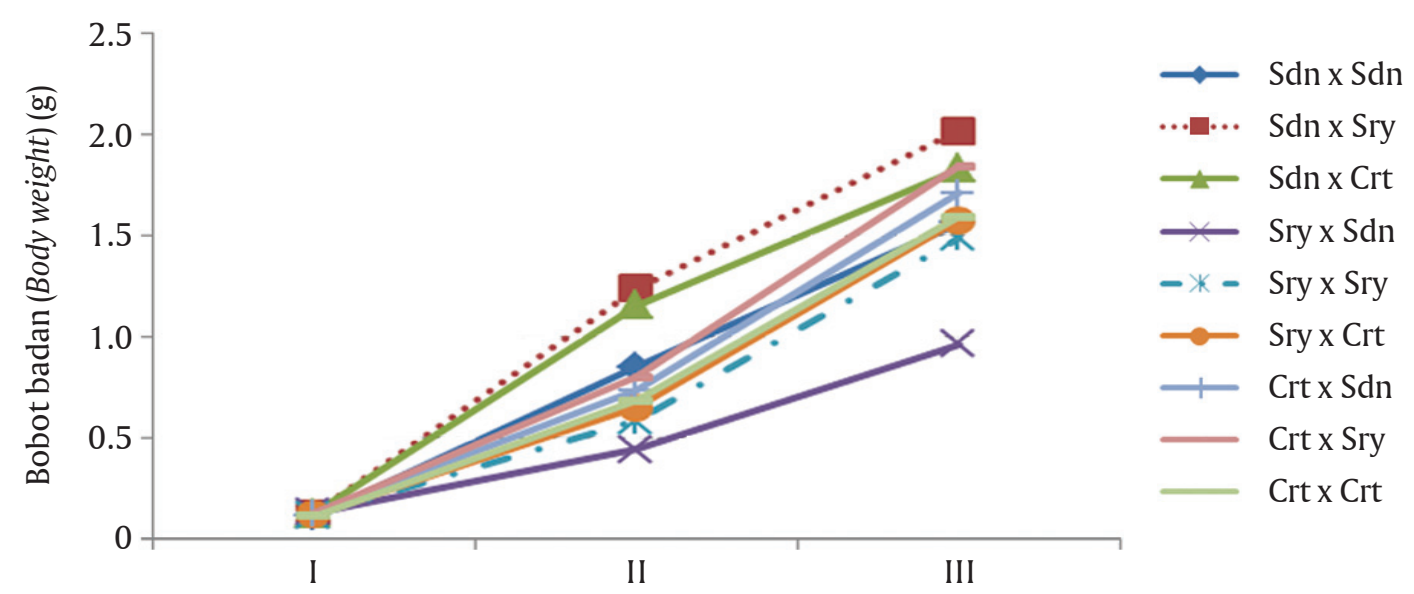

Pengamatan setiap dua minggu (Observation every two weeks)

Gambar 3. Pertumbuhan bobot benih baung sampai dengan umur enam minggu hasil persilangan secara resiprok pada ketiga populasi yaitu Cisadane, Serayu, dan Cirata

Figure 3. Growth weight of resiprocally cross-breeding of six weeks green catfish fry from three different population; Cisadane (Sdn), Serayu (Sry), and Cirata (Crt)

han lebih tinggi, serta peran jantan atau betina apabila disilangkan dengan setiap populasi akan menghasilkan pertumbuhan lebih baik.

Derajat sintasan benih tertinggi dihasilkan dari persilangan $\mathrm{Crt} \times \mathrm{Crt}$ dan terendah pada persilangan Sdn x Sdn (Tabel 4). Berdasarkan analisis ragam, rataan sintasan menunjukkan perbedaan sangat nyata $(\mathrm{P}<0,01)$. Nilai SR terbaik terdapat pada persilangan Crt x Crt sebesar 35,17 $\pm 21,495 \%$; dan yang terendah adalah pada persilangan $\operatorname{Sdn} \times \operatorname{Sdn}(0,42 \pm 0,722 \%)$.

Konstribusi induk betina dan jantan terhadap derajat sintasan benih tertinggi didominasi oleh populasi Sdn, diikuti oleh populasi Sry dan Crt (Tabel 4). Berdasarkan analisis ragam, konstribusi induk betina dan jantan terhadap sintasan menunjukkan perbedaan nyata $(P<0,05)$, dan nilai tertinggi dicapai oleh po- pulasi Sdn $(1.596,43 \%)$ pada betina, sedangkan pada induk jantan sebesar 933,33\%.

Nilai heterosis positif terbesar pada karakter SGR ditunjukkan oleh persilangan satu arah antara Sdn dengan Sry sebesar $8,72 \%$; sedangkan terendah ditunjukkan oleh persilangan satu arah antara Sry dengan Sdn -27,10\%. Untuk karakter sintasan nilai heterosis dua arah menunjukkan nilai negatif pada semua hasil persilangan, namun persilangan dua arah antara $\mathrm{Crt}$ dan Sdn menunjukkan nilai negatif terkecil $(-3,04 \%)$. Pada karakter bobot akhir, nilai heterosis positif tertinggi diperoleh oleh persilangan dua arah Sdn dengan Crt adalah 14,34\%; sedangkan terendah pada persilangan dua arah populasi Sdn dan Sry $(-4,01 \%)$. Penggabungan dari karakter SR dan bobot akhir rataan nilai heterosis menunjukkan nilai tertinggi yaitu pada persilangan dua arah antara Sdn dan Crt sebesar 5,65\%; 
Tabel 3. Laju pertumbuhan spesifik / SGR (\%), maternal, dan individual effect benih ikan baung hasil persilangan resiprok tiga populasi

Table 3. Spesific growth rate (\%), maternal, and individual effect of resiprocally cross-breeding of green catfish from three different population

\begin{tabular}{|c|c|c|c|c|c|c|}
\hline \multirow{2}{*}{\multicolumn{2}{|c|}{$\begin{array}{l}\text { Sumber genetik induk } \\
\text { Genetic resources of } \\
\text { broodstock }\end{array}$}} & \multicolumn{3}{|c|}{ Jantan (Male) } & \multirow{2}{*}{$\begin{array}{c}\text { Pengaruh } \\
\text { induk } \\
\text { Maternal effect }\end{array}$} & \multirow{2}{*}{$\begin{array}{c}\text { Pengaruh } \\
\text { individu } \\
\text { Individual effect }\end{array}$} \\
\hline & & Sdn & Sry & Crt & & \\
\hline \multirow{3}{*}{ Betina (Female) } & Sdn & $4.93 \pm 0.146^{\mathrm{bc}}$ & $5.27 \pm 0.216^{\mathrm{bc}}$ & $5.09 \pm 0.156^{\mathrm{bc}}$ & 5.07 & 8.72 \\
\hline & Sry & $3.53 \pm 0.080^{\mathrm{d}}$ & $4.76 \pm 0.532^{c}$ & $5.43 \pm 0.331^{\mathrm{b}}$ & -5.88 & -37.61 \\
\hline & Crt & $4.96 \pm 0.076^{\mathrm{bc}}$ & $5.11 \pm 0.139^{b c}$ & $6.10 \pm 0.161^{\mathrm{a}}$ & -17.46 & 4.34 \\
\hline
\end{tabular}

Keterangan (Note):

Huruf superscript di belakang nilai standar deviasi yang berbeda pada setiap baris menunjukkan berbeda sangat nyata $(\mathrm{P}<0,01)$ (The value followed by different superscript in the same row were significantly different $(P<0.01))$

Tabel 4. Sintasan (SR) (\%) benih ikan baung hasil persilangan resiprok tiga populasi

Table 4. Survival rate (\%) of juvenile derived from resiprocally cross-breeding of green catfish obtained from three different population

\begin{tabular}{|c|c|c|c|c|c|c|}
\hline \multirow{2}{*}{\multicolumn{2}{|c|}{$\begin{array}{l}\text { Sumber genetik induk } \\
\text { Genetic resources of } \\
\text { broodstock }\end{array}$}} & \multicolumn{3}{|c|}{ Jantan (Male) } & \multirow{2}{*}{$\begin{array}{c}\text { Pengaruh } \\
\text { induk } \\
\text { Maternal effect }\end{array}$} & \multirow{2}{*}{$\begin{array}{c}\text { Pengaruh } \\
\text { individu } \\
\text { Individual effec }\end{array}$} \\
\hline & & Sdn & Sry & Crt & & \\
\hline \multirow{3}{*}{ Betina (Female) } & $\operatorname{Sdn}$ & $0.42 \pm 0.722^{\mathrm{h}}$ & $1.25 \pm 1.750^{\mathrm{g}}$ & $13.00 \pm 8.128^{\mathrm{d}}$ & $1,596.43$ & 933.33 \\
\hline & Sry & $6.00 \pm 3.307^{\mathrm{h}}$ & $7.83 \pm 8.980^{\mathrm{e}}$ & $7.75 \pm 7.774^{\mathrm{ef}}$ & -12.20 & -327.84 \\
\hline & Crt & $21.50 \pm 20.732^{c}$ & $22.25 \pm 24.466^{b}$ & $35.17 \pm 21.495^{\mathrm{a}}$ & -37.80 & 40.39 \\
\hline
\end{tabular}

Keterangan (Note):

Huruf superscript di belakang nilai standar deviasi yang berbeda pada setiap baris menunjukkan berbeda sangat nyata $(\mathrm{P}<0,01)$ (The value followed by different superscript in the same row were significantly different $(P<0.01))$

sedangkan nilai terendah yaitu $-9,72 \%$ pada persilangan dua arah antara Sry dan Crt (Tabel 5).

Rata-rata fekunditas dan nilai indeks ova somatik tertinggi yang diperoleh dari induk betina Cirata diperoleh akibat dari rata-rata diameter telur yang lebih kecil dibanding telur yang diperoleh dari populasi lain. Selain itu, populasi induk Cirata merupakan populasi yang telah lama dipelihara dalam kondisi lingkungan budidaya sehingga lebih mampu beradaptasi dengan pakan buatan yang diberikan. Secara umum, fekunditas ikan baung dalam penelitian ini hampir sama nilainya dengan penelitian Utiah (2006) yang mengamati pengaruh kandungan asam lemak berbeda dalam pakan terhadap fekunditas telur ikan baung, yaitu antara 40,53 sampai 68,70 butir telur per gram bobot induk betina.

Kualitas telur dipengaruhi oleh karakteristik induk betina, baik secara genetik, stres, kondisi, ukuran badan, masa bereproduksi dan dengan pengecualian pada faktor genetik, karakter-karakter ini berkaitan dengan variasi musiman. Ukuran telur merupakan hal yang paling sederhana dan umum digunakan untuk menentukan kualitas telur. Data yang ada menunjuk- kan adanya korelasi positif antara ukuran telur dan sintasan larva.

Rendahnya nilai SR rata-rata dari peran betina Sdn pada semua persilangan $\left(4,89 \pm 7.037^{\circ}\right)$ diduga akibat populasi ini belum teradaptasi pada kondisi lingkungan budidaya, yang berakibat ikan menjadi mudah stres dan yang berakhir dengan kematian. Faktor umum yang menyebabkan sintasan ikan baung menjadi rendah diakibatkan oleh kualitas telur, sifat kanibalisme, serta kerentanan pada serangan jamur Ich pada tahap benih.

Doroshov \& van Eenennaam (2000) melaporkan pengaruh kualitas pakan terhadap pertumbuhan, kematangan ovari, dan kualitas telur pada ikan sturgeon. Palacios et al. (2002) melaporkan komposisi lemak dan asam lemak dalam telur berhubungan erat dengan sintasan larva, komposisi fosfolipid spesifik pada telur penaeid dapat digunakan (berpotensi) sebagai indikator kualitas larva. Untuk pengembangan lebih lanjut dari hasil eksplorasi hibridisasi ini, teknologi budidaya yang memungkinkan dapat diaplikasikan untuk menekan sifat kanibalisme agar dicapai sintasan pada fase benih tinggi yaitu dengan meningkat- 
Tabel 5. Nilai heterosis dari persilangan ke-3 populasi ikan baung asal Cisadane, Serayu, dan Cirata

Table 5. Resiprocally cross-breeding of green catfish fry heterosis value (\%) from three different population, Cisadane, Serayu, and Cirata

\begin{tabular}{|c|c|c|c|c|c|c|c|c|}
\hline \multirow{2}{*}{$\begin{array}{l}\text { Sumber genetik } \\
\text { induk } \\
\text { Genetic resources } \\
\text { of broodstock }\end{array}$} & \multicolumn{6}{|c|}{ Heterosis (\%) } & \multirow{2}{*}{\multicolumn{2}{|c|}{$\begin{array}{c}\text { Rataan heterosis } \\
\text { sintasan dan bobot } \\
\text { Average heterosis of survival } \\
\text { rate and body weight }(\%)\end{array}$}} \\
\hline & \multicolumn{2}{|c|}{$\begin{array}{c}\text { Pertumbuhan } \\
\text { bobot spesifik } \\
\text { Specific growth rate }\end{array}$} & \multicolumn{2}{|c|}{$\begin{array}{c}\text { Sintasan } \\
\text { Survival rate }\end{array}$} & \multicolumn{2}{|c|}{$\begin{array}{c}\text { Bobot akhir } \\
\text { Final body weight }\end{array}$} & & \\
\hline Sdn x Sry & 8.72 & \multirow{2}{*}{-9.19} & -69.70 & \multirow{2}{*}{-12.12} & 20.57 & \multirow{2}{*}{-4.01} & -24.565 & \multirow{2}{*}{-8.07} \\
\hline Sry x Sdn & -27.10 & & 45.45 & & -28.59 & & 8.43 & \\
\hline $\operatorname{Sdn} \times \mathrm{Crt}$ & -7.79 & \multirow{2}{*}{-8.95} & -26.93 & \multirow{2}{*}{-3.04} & 6.60 & \multirow{2}{*}{14.34} & $-10,165$ & \multirow{2}{*}{5.65} \\
\hline Crt $x$ Sdn & -10.10 & & 20.84 & & 22.08 & & 21.46 & \\
\hline Sry x Crt & -0.01 & \multirow{2}{*}{-2.99} & -63.95 & \multirow{2}{*}{-30.23} & 2.13 & \multirow{2}{*}{10.79} & -30.91 & \multirow{2}{*}{-9.72} \\
\hline Crt x Sry & -5.97 & & 3.49 & & 19.46 & & 11.475 & \\
\hline
\end{tabular}

kan frekuensi dan ransum pakan, hal tersebut sesuai dengan yang telah dilakukan oleh Baras et al. (2010).

Sifat kanibalisme sangat dipengaruhi konsentrasi hormon serotonin. Riset yang dilakukan oleh Hseu et al. (2003) pada yuwana ikan kerapu membuktikan bahwa kanibalisme dipengaruhi oleh tingkat konsentrasi hormon serotonin pada otak. Serotonin (5-hydroxytryptamine, 5-HT) adalah suatu neurotransmitter mono-amino yang disintesiskan pada neuron-neuron serotonergis dalam sistem saraf pusat dan sel-sel enterokromafin dalam saluran pencernaan. Peningkatan hormon serotonin diduga mampu mengurangi kecenderungan sifat agresif kanibalisme. Konsentrasi hormon serotonin ini dapat dipicu oleh penambahan zat scopoletin.

Kedua karakter ini yang mungkin lebih diutamakan pada segmen produksi benih. Dengan demikian pemilihan induk untuk tujuan produksi benih antara populasi asal Cisadane dan Cirata bisa dilakukan, hal tersebut didukung dengan produktivitas yang dihasilkan oleh kedua populasi tersebut tinggi seperti nilai IOS (Indeks Ova Somatik) Sdn 15,9\% dan Crt 20,7\%.

Rendahnya nilai heterosis yang dihasilkan dalam penelitian ini bisa disebabkan oleh masih tingginya keragaman genetik induk yang digunakan. Cassady et al. (2002) mengemukakan bahwa dalam usaha untuk memperbaiki aktivitas diastatik gen yang memunculkan efek heterosis yang dikehendaki, perlu dilakukan seleksi secara ketat dan berulang pada kedua tetuanya terhadap sifat yang akan digabungkan, untuk memperoleh kedua tetua yang betul-betul baik dalam memunculkan heterosis yang baik pula. Cassady et al. (2002) mengemukakan bahwa efek heterosis positif yaitu rata-rata penampilan suatu karakter keturunan hasil persilangan melebihi rata-rata penampilan kedua tetuanya, sedangkan efek hetero- sis negatif adalah rata-rata penampilan suatu karakter keturunan hasil persilangan yang lebih rendah dari rata-rata penampilan kedua tetuanya. Penampilan yang berhubungan dengan produksi pada umumnya heterosis positif, sedangkan penampilan reproduksi pada umumnya heterosis efek negatif.

Faktor genetik, kekerabatan, dan aksi gen memengaruhi nilai heterosis. Aksi gen terdiri atas aksi gen aditif dan tidak aditif. Menurut Ariyanto \& Subagyo (2004), nilai heterosis sangat dipengaruhi oleh aksi gen tidak aditif, sedangkan aksi gen aditif cenderung memengaruhi nilai heritabilitas dalam suatu karakter. Secara umum, nilai heterosis pada kegiatan persilangan ini relatif rendah mengarah pada nilai negatif. Hal ini mengindikasikan bahwa pengaruh gen tidak aditif hasil persilangan tiga populasi baung yang digunakan pada karakter pertumbuhan relatif kecil.

Pemilihan sumber genetik yang tepat tentu saja akan meningkatkan kualitas fenotipe heterozigot hibridisasi. Secara genetis persilangan mampu menambah keragaman genetik, serta menyatukan keunggulan dari masing-masing strain kepada keturunan hasil persilangannya. Namun keragaman genetik yang tinggi belum tentu menghasilkan benih hasil persilangan dengan performa yang baik, hal tersebut bergantung kepada intensitas gen yang memiliki sifat keunggulan. Gen tersebut akan terekspresi secara maksimal atau tidak terekspresi erat hubungan dengan kondisi lingkungan budidaya. Potensi genetik tidak dapat terekspresi dengan baik tanpa dukungan lingkungan (Dunham, 2004).

\section{KESIMPULAN}

Persilangan intraspesifik antara ikan baung Sdn dan Sry menghasilkan laju pertumbuhan spesifik (SGR) terbaik, sintasan (SR) benih terbaik diperoleh dari 
persilangan searah antara Sry $x$ Sdn dengan nilai heterosis $45,45 \%$. Bobot akhir terbaik diperoleh dari persilangan antara Crt dan Sdn dengan nilai heterosis $22,08 \%$. Nilai tertinggi SGR dari persilangan dua arah adalah populasi Sry dan Crt, pada parameter SR $(-3,04)$; sedangkan bobot akhir adalah pada Sdn dan Crt (5,56\%). Berdasarkan pemilihan beberapa karakter, persilangan dua arah antara populasi Cisadane dan populasi Cirata adalah persilangan dengan respons tertinggi pada parameter SR dan bobot akhir tertinggi, didukung dengan produktivitas kedua populasi tersebut tinggi.

\section{UCAPAN TERIMA KASIH}

Penulis mengucapkan terima kasih kepada Tedih, Supendi, Deni Irawan, dan Iskandariyah atas bantuannya selama pelaksanaan riset. Penelitian ini dibiayai oleh DIPA 2012 Balai Penelitian dan Pengembangan Budidaya Air Tawar, Bogor.

\section{DAFTAR ACUAN}

Ariyanto, D., \& Subagyo. (2004). Variabilitas genetik dan evaluasi heterosis pada persilangan antar galur dalam spesies ikan mas. Zuriat, 15, 118-124.

Baras, E., Hafsaridewi, R., Slembrouck, J., Priyadi, A., Moreau, Y., \& Pouyaud, L. (2014). Do cannibalistic fish possess an intrinsic higher growth capacity than others? A case study in the Asian redtail catfish Hemibagrus nemurus (Valenciennes, 1840). Aquaculture Research, 45(1), 68-79. DOI: 10.1111/ j.1365-2109.2012.03205.x.

Boyoun, H.S., Catur, S. \& Yudi, Y. 2010. Cara mudah Budidaya ikan Baung dan Peluang Bisnis Jelawat., IPB Press, $161 \mathrm{hlm}$.

Cassady, P.J., Yung, L.D., \& Leymaster, K.A. (2002). Heterosis and rekombinant effects on pig reproductive traits. J. Anim. Sci., 20(9), 2303-2315.

Doroshov, S.I., \& van Eenennaam, J.P. (2000). White sturgeon domestic broodstock management. Reporting Period No. 4/01/99-3/31/00.

Dunham, R.A. (2004). Aquaculture and fisheries biotechnology genetic approaches. CABI Publishing. London.

Hseu, J.R., Lu, F.I., Wang, H.M.S,L.S., Tsai, C.L., \& Wang, P.P. (2003). Effect of exogenous tryptophan on canibalism, survival, and growth juvenile grouper, Epinephelus coicoides. J. Aquaculture, p. 0-12.
Kurniasih, T., \& Gustiano, R. (2007). Hibridisasi sebagai alternatif untuk penyediaan ikan unggul. Media Akuakultur, 2, 37-40.

Lawrence, C.S., Morrissy, N.M., Vercoe, P.E., \& Williams, I.H. 2000. Hybridization in Australian freshwater crayfish-production of all-male progeny. Journal of the World Aquaculture Society, 31(4), 651-658.

Nugroho, E., Hadie, W., \& Sudarto. (2003). Variasi genetik ikan baung Mystus nemurus dari beberapa waduk di Jawa yang dianalisis dengan marker mitokondria D-Loop. J. Pen. Perik. Indonesia, 9(1), 1-4.

Palacios, E., Racotta, I.S., Heras, H., Marty, Y., Moal, J., \& Samain, J-F. (2002). Relation between lipid and fatty acid composition of eggs and larval survival in white pacific shrimp (Penaeus vannamei, Boone, 1931). Aquaculture International, 9(6), 531543.

Singh, R.K., \& Chaudhary, B.D. (1977). Biometrical methods in quantitative Genetic Analysis (Revised Edition). Kalyani Publishers. New Delhi, India.

Subagja, J, Nugroho, E., \& Nafiqoh, N. (2011). Variasi genetik dan performa bioreproduksi beberapa strain ikan baung (Hemibagrus nemurus) sebagai langkah awal dalam perbaikan mutu induk. Prosiding FITA 2011.

Taukhid, Komarudin, O., Supriyadi, H., \& Bastiawan, D. (2005). Strategi pengendalian penyakit pada budidaya ikan air tawar. Strategi pengelolaan dan pengendalian penyakit KHV. Pusat Riset Perikanan Budidaya. Jakarta, hlm. 17-29.

Tave, D. (1995). Selective breeding programs for medium-sized fish farm. FAO Fisheries Technical Paper 352. FAO Rome, 122 pp.

Utiah, A. (2006). Penampilan reproduksi induk ikan baung (Hemibagrus nemurus Blkr) dengan pemberian pakan buatan yang ditambahkan asam lemak N-6 dan N-3 dan dengan implantasi estradiol-17 $\beta$ dan tiroksin. Disertasi. Sekolah Pascasarjana. Institut Pertanian Bogor. Bogor, $104 \mathrm{hlm}$.

Wuwungan, H. (2009). Keragaan benih udang galah Macrobrachium rosenbergii hasil perkawinan secara inbreeding, outbreeding, dan crossbreeding. Skripsi. Fakultas Perikanan dan Ilmu Kelautan, Institut Pertanian Bogor. Bogor. 